\title{
MITOISTA, KÄSITTEISTÄ JA KÄSITTÄMISESTÄ
}

Tuukka Perhoniemi: Mitan muunnelmat. Miten määritämme maailmaa, ihmistä ja tietoa. Tampere: Vastapaino 2014.

Tuukka Perhoniemen tutkielma mitan muunnelmista on monella tavoin sekä informatiivinen että innostava teos. Toisaalta sen kokonaishahmo herättää myös joukon kriittisiä kysymyksiä. Teoksen pääosassa on mitta. Ensisijaisesti Perhoniemeä ei kuitenkaan kiinnosta, miksi ihmiset ovat mitanneet ja mitä ihmiset ovat tehneet mitatessaan, vaan hänen kiinnostuksensa kohteena on mitan (mittojen) luonne historiallisena ilmiönä. Tutkielmansa lyhyessä johdantoluvussa Perhoniemi esittää joukon mittoja koskevia kysymyksiä ja jatkaa (s. 9; kursivointi alkutekstissä):

Kysymykset koskevat mittauskäytäntöjen taustalla vaikuttavia perustavia periaatteellisia ja käsitteellisiä rajauksia ja erotteluja sekä niihin sisältyviä oletuksia todellisuuden luonteesta ja suhteestamme siihen. [...] Tämä tarkoittaa mittojen ja mittaamisen käsitteellisen luonteen pohtimista - erotukseksi esimerkiksi mittateorioiden tai yksittäisten mittojen ja mittaamisen teknisten piirteiden ja mahdollisuuksien tarkasteluun.

Tavoitteenasettelu herättää kysymyksen: Mitä mittojen "käsitteellinen luonne" tarkoittaa? Tutkielmassa se tarkoittaa kahta asiaa: Yhtäältä Perhoniemi jättää taakseen kaikki ne lukemattoman moninaiset mittaamiseen tähdänneet toimet, joiden avulla ihmiset ovat jäsentäneet ja luoneet olemassaolonsa aineellisia ehtoja. Hän on toki perillä tästä moninaisuu- desta ja viittaa siihen useassa kohdassa, mutta ei juuri kiinnitä huomiota eri tilanteiden erilaatuisuuteen. Palaan tähän jäljempänä.

Toisaalta hän olettaa, että mittaamisen taustalle voidaan konstruoida jokin eri aikakausille ominainen kokonaisvaltainen mittaamista määrittävä näkemys. Teoksensa laajassa metodologisessa liitteessä hän tarkentaa oman näkökulmansa fenomenologiseksi historiantutkimukseksi ja jatkaa (s. 202): "Suuremman painon [kuin tosiasiahistoria tai rationaalinen rekonstruktio] saa sen esittäminen, miten jokin tietty ajatus ilmenee ajattelun kokonaisuudessa."

Lukija valpastuu. "Ajattelun kokonaisuus" on olennaisesti eritasoinen ilmiö kuin ne moninaiset toimet, joiden yhteydessä esineitä ja asioita mitataan ja verrataan tulosten perusteella toisiinsa jotakin erityistä kriteeriä käyttäen. Onnistuuko Perhoniemi ottamaan huomioon tasojen välityksen? Vai häviääkö jotakin mittojen ymmärtämisen suhteen olennaista ajattelun kokonaisuuden kuvauksen alle?

Perhoniemi käyttää tutkielmansa empiirisessä osassa välineenään kolmea osatutkimusta, jotka kohdistuvat antiikin filosofiaan sekä 1600-luvun ja 1800-luvun tieteellisiin murroksiin. Näiden aikakausien analyysiin hän perustaa ideansa mitan muunnelmista. Hän löytää jokaiselta aikakaudelta oman sille ominaisen muunnelman, joita hän luonnehtii edellisen listan mukaisesti" (n)ämä luonnehdinnat ovat ontologinen, representatiivinen ja toiminnallinen" (s. 16; kursivointi alkutekstissä). Osatutkimukset muodostavat tutkielman pääasiallisen sisällön.

Tutkielman ongelmanasettelu ei kuitenkaan rajoitu tähän. Tapaustutkimusten pällle 
Perhoniemi pystyttää kolmannen tason, joka käsittää sen, mitä hän haluaa tutkielmallaan varsinaisesti sanoa. Johdantoluvun lopuksi hän kuvaa tavoitteensa seuraavasti (s. 18):

Käsittelemieni tapaustutkimusten avulla ymmärrämme paremmin niitä edellytyksiä, jotka määrittävät ajattelutapojamme elämän eri alueilla. Mitan muunnelmat kertovat erilaisista näkökulmista, kiinnostuksista ja käytännöistä, vaativat mielekkään kontekstin, saattavat kaukaisia asioita yhteen ja vertailukelpoisiksi, tuovat esille näkymättömiä asioita ja mahdollistavat erilaisia jatkotoimia. Näin ne ovat myös hallinnan välineitä. Ne antavat perusteltuja tulkintavaihtoehtoja erilaisille nykyisin tehtäville mittauksille ja niissä käytetyille sekä niistä saaduille mitoille. Viime kädessä ne koskevat maailman järjestystä, ihmisenä olemista ja inhimillisen tiedon luonnetta.

Lukija valpastuu jälleen. Perhoniemi lupaa siirtyä mitan muunnelmista ihmisenä olemisen yleisiin ehtoihin ja niitä koskevaan ymmärrykseen. Herää samansukuinen kysymys kuin edellä: Ovatko välitykset hallinnassa?

Koska tapaustutkimuksia käsittelevät luvut muodostavat teoksen pääsisällön, jatkan niistä. Ensimmäisessä osatutkimuksessa "Antiikin kosmos ja sen järjestys" Perhoniemi käsittelee ensisijaisesti Platonin ja Aristoteleen tekstejä sekä kohtuullisen laajasti heitä myöhempiä hellenistisen kauden ajattelijoita, erityisesti matemaatikoita. Luku perustuu näiltä osin hyvään lähdeaineiston hallintaan ja selvästi myös alkutekstien tuntemukseen. Tämän suhteen se on kirjan luvuista helpoin: antiikin Kreikan tärkeitä ajattelijoita on suhteellisen vähän, ja heidän ajatustensa tärkeä tulkintakirjallisuus, vaikka onkin laaja, on jokseenkin hallittavissa. Luku on siinä suhteessa perusteellinen ja tarkka sekä sujuvasti kirjoitettu (kuten koko kirjakin).

Luvun hallitsevan näkökulman muodostavat Platon ja ideaalisen mitan käsite. Perhoniemen antama kuva Platonista on kuvattavansa näköinen. Platoniin hän myös perustaa atribuutin "ontologinen", jolla hän luonnehtii tulkintaansa kreikkalaisesta mitan muunnelmasta (s. 41): "Koko kosmos on järjestynyt mittojen mukaan, joiden välisiä suhteita filosofit selvittävät mittaustaidoillaan. Mitta on siis ontologinen käsite."

Pidän tätä hankalana tulkintana. Platonin kosmokseen kytketty mitta varmaankin voidaan tulkita ontologiseksi, mutta Platonin mitan taustalla olivat antiikin yhteiskuntien käytännölliset mittaustaidot. Perhoniemi kuittaa Platonia edeltäneen historian seuraavasti (s. 28-9; lainausmerkit ja kursivointi alkutekstissä):

Ensimmäisillä "filosofeilla", Thalella ja kumppaneilla, oli jo hyvin toimivia abstraktioita heidän tehdessään mittauksia ja pohtiessaan kosmoksen järjestystä. Se, mitä heillä ei ollut, tai mikä ei ainakaan ole säilynyt meille arkeologisten eikä kirjallisten lähteiden muodossa, on muualla kuin geometriassa käytetty ideaalisen mitan käsite, jota he olisivat eksplisiittisesti pohtineet.

Miksi "ideaalisen mitan käsite" olisi kiinnostavin mittaamiseen liittyvä ajatus, minkä antiikki meille tarjoaa? Pidän mittaamisen käytäntöjä huomattavasti kiinnostavampina. Perhoniemellä kuitenkin välitys käytännön toimeentuloa palvelevasta mittaamisesta mitan käsitteeseen jää puuttumaan. Harmi: mitat ja mittaamisen idea ovat kasvaneet esiin noista käytännöistä. Ateenan klassisen kauden filosofit, erityisesti Platon ja hänen seuraajansa, sysäsivät käytännöllisen taustan syrjään. Mittaamisen kaltaisia toimintoja arvioitaessa taustalla olleet käytännöt tulisi palauttaa kunniaan.

Käyttökelpoisen näkökulman mittaamisen varhaiseen historiaan tarjoaisi mittaamisen arkeologia. Perhoniemi viittaa tutkielmansa alkusivuilla teokseen The Archaeology of Measurement (Morley \& Renfrew 2010), mutta ei sitä sen koommin käytä. Olisi kannattanut käyttää. Kokoelman esseistä käy ilmi se Perhoniemen pyrkimyksen kannalta olennainen seikka, että 
erilaisia mittoja on kautta aikojen kehitetty tukemaan toimintoja, jotka ovat olleet inhimillisten yhteisöjen toimeentulolle välttämättömiä. Iain Morley, toinen kokoelman toimittajista, ottaa esiin viisi jonkinlaista kvantitatiivista arviointia edellyttäneiden toimintojen aluetta teoksen johdantoluvussa "Conceptualizing quantification before settlement: Activities and issues underlying the conception and use of measurement"; ne ovat: (1) ryhmän jäsenten keskinäiset suhteet, (2) resurssit ja hyödykkeet, (3) ympäröivän maailman luonnolliset ja ihmisperäiset piirteet, (4) suunnistaminen ja navigaatio (sekä maalla että merellä) sekä (5) aika.

Morley viittaa tässä myöhäisen paleoliitin sekä mesoliitin metsästäjä-keräilijöiden yhteisöihin; nykyisen Euroopan alueella nämä ajanjaksot kattoivat kymmeniä tuhansia vuosia ennen maanviljelystä ja paikalleen asettuneita yhteisöjä eli neoliittista kautta. Metsästäjä-keräilijöiden yhteisöjen jäsentyminen ja vakiintuminen edellyttivät mittaamistaitoja, jotka loivat osaltaan perustan paikalleen asettuneille yhteisöille. Paikalleen asettuneista yhteisöistä kasvoivat muutaman tuhannen vuoden polveilevan historian kuluessa Lähi-Idän sivilisaatiot ja kaupunkivaltiot, lopulta antiikin Kreikan polis. Tässä polveilevan kehityksen kulussa muotoutuivat ja vakiintuivat työnjako, hallinnon järjestelmät, kirjoitustaito sekä systemaattinen käsitteellinen ajattelu. Käsitteellinen ajattelu teki Platonin mahdolliseksi. Platonille puolestaan oli mahdollista unohtaa käsitteellistä ajattelua edeltänyt käytännölliseen tietoon perustunut järjestynyt elämä - tai ainakin sen "tietoteoreettinen" merkitys. Pitäytyminen siihen, mitä Platon kirjoitti, antaa käytännöllisen elämän aihepiireistä hyvin vajavaisen kuvan.

Perhoniemi siteeraa (s. 41) dialogia Filebos, jossa Platon (eli Sokrates) tekee erottelun "tavallisten ihmisten mittaustaidon" ja "filosofien mittaustaidon" välille. Tässä ei kuitenkaan ole kyse pelkästään mittaustaidosta (joka ei ollut platonilaisten filosofien vahvinta osaamista) vaan käytännöllisten taitojen arvostuksesta ylimalkaan. Vernant (2006) esittää platonilai- sesta käytännöllisten taitojen väheksynnästä esimerkkejä, joista yksi on juuri dialogista $F i$ lebos (55e) (suom. Marianna Tyni):

SOKRATES: Tarkoitan tätä: jos poistamme erilaisista käytännön töistä tiedon laskemisesta, mittaamisesta ja punnisemisesta, ei siitä, mitä jää jäljelle, ole enää mihinkään. [...] Se, mitä jää jäljelle, on työskentelyä arviokaupalla ja kokemuksen tuomalla sormituntumalla ja turvautumisella siihen vaivalloisella harjoittelulla saavutettavaan vaistomaiseen kykyyn, jota ihmiset sanovat ammattitaidoksi.

Platonia (Sokratesta) edeltävien aikojen mittaustavat ja -taidot ovat kuitenkin mitä mielenkiintoisin osa antiikin perintöä. Arkkitehtuurin historioitsija Indra Kagis McEwen (1993) löytää kreikkalaisesta historiasta vahvoja osoituksia siitä, että käytännöllisiä taitoja pidettiin ennen kaupunkivaltioiden kukoistuskautta suuressa arvossa. Hiukan pelkistäen hänen vastauksensa käytännöllis-teknisten taitojen alkuperään on Daidalos, demiurgi. Daidalos oli erityisesti käsityötaidoistaan tunnettu myyttinen hahmo, jonka tausta ulottuu homeeriseen hämärään sekä maantieteellisesti kauas Välimeren itäpuolen kulttuureihin. Sokrates mainitsi parissakin Platonin dialogissa olevansa Daidaloksen jälkeläinen, koska hänen isänsä oli rakentaja - tosin hiukan pejoratiivisessa sävyssä. Siitä kumminkin McEwenin teoksen otsikko: Socrates' Ancestor.

McEven korostaa erityisesti, että käytännön toimilla oli perustaa luova (konstitutiivinen) merkitys kaupunkivaltioiden muodostumiselle; tässä hänen tärkeä edeltäjänsä on ollut toinen arkkitehtuurin historioitsija, Joseph Rykwert. On hyvin uskottavaa, että mittaamiskyvyn tuottama mahdollisuus verrata asioita toisiinsa ja asettaa niitä arvojärjestykseen on kantanut olennaisesti symbolisia merkityksiä. Nämä symboliset merkitykset eivät niinkään olleet sidoksissa yhtenäiseen ontologiaan (platonilaiseen "kosmokseen"; kuten McEwen toteaa, termi "kosmos" ei alunperin viitannut maail- 
manjärjestyksen kokonaisuuteen vaan järjestykseen, joka kasvoi esiin tai ilmaantui toiminnan välityksellä moninaisissa konkreettisissa muodoissa). Antropologi Clive Gamble (2007) käyttää ihmistoimia ohjaavien artefaktien ja luonnon ainesten symbolisesta merkityksestä termiä "symbolinen voima" (symbolic force). Hänen ajatuksensa on, että ihmisten materiaalista ympäristöä jäsentävät symboliset merkitykset "tempaavat mukaansa" osallistumaan toimeentulolle välttämättömiin toimiin oikeaan aikaan oikeassa paikassa. Näinhän esimerkiksi maatalouteen liittyvät toimet ovat saaneet käynnistysvoimansa perinteisissä yhteisöissä.

Symbolit olivat keskeinen osa antiikin yhteisöjen elämää, ja monet keskeisen tärkeät symbolit perustuivat mittaamiseen. Siinä oli esimerkiksi trigonometrian taitavan hallinnan perusta. Perhoniemi toki tunnistaa maanmittaustaitojen merkityksen, mutta lisää sitä koskevaan kohtaan teostaan huomautuksen (s. 22): "On helppo kuvitella egyptiläinen köydenpingoittaja mittailemassa 3000 vuotta sitten Niilin tulvien jälkeen maa-alueita ja rajoja sellaisella tavalla, joka on meille nykypäivänäkin ymmärrettävissä.” - Ei sentään! Niilin tulvat hävittivät viljelypalstojen rajat kaikkialla samanaikaisesti, ja ne piti kiireesti palauttaa näkösälle uutta kylvökautta varten. Rajojen määrittäminen oli tiukasti sidottu pappisylimysten erityiseen symbolisella ja tarvittaessa fyysisellä vallalla turvattuun erityisasemaan. En usko, että me nykyihmiset kokisimme menettelyn erityisen kotoisaksi.

Vastaavanlainen käytännöllisperäinen ja tarkoin pyhitetty suhde vallitsi siirtokuntien perustamisen yhteydessä toteutetun kaupunkipalstojen jaon ja maanmittauksen välillä. Ilman papiston panosta ja suotuisien enteiden tarjoamaa turvaa uusien kaupunkien perustamisesta ei olisi tullut mitään; Rykwert (1988) antaa tästä seikkaperäisen kuvan.

Käytännöllisten taitojen arvostus tuli hävitetyksi platonilaisen tietoteorian taakse. Miksi näin kävi, on toinen kysymys, jonka pohtimiseen ei tässä yhteydessä ole edellytyksiä.
Perhoniemi kohdistaa toisen, 1600-luvun tieteellistä murrosta käsittelevän osatutkimuksensa"Galilein mittaukset kuvauksina luonnosta” Galileo Galilein perintöön. Hän on tässäkin tapauksessa selvästi lukenut kattavasti alkuperäislähteitä sekä myös laajalti tulkintakirjallisuutta. Tulkitsijoiden työn kartoittaminen on kuitenkin 1600-luvun tieteen osalta hankalampi tehtävä kuin antiikin tieteen osalta. Galilein työtä suoranaisesti analysoivan kirjallisuuden Perhoniemi kattaa hyvin, mutta Galilein sijoittaminen toimintayhteyteensä jää ohueksi. Tämä on valitettava rajoite. Jos Galilein mittanäkemysten olettaa Perhoniemen tavoin ilmentävän aikakauden "ajattelun kokonaisuutta", kontekstualisointi olisi välttämätöntä.

Toisen osatutkimuksensa perusteella konstruoimansa mitan muunnelman Perhoniemi esittelee seuraavasti (s. 106; kursivoinnit alkutekstissä):

(M)itan suora ontologinen sidos mitattavaan jää epäselväksi tai toissijaiseksi ja mitta pikemminkin kuvaa mitattavaa. Siksi kutsun niiden pohjalta hahmottelemaani mitan muunnelmaa kuvailevaksi eli representatiiviseksi. Luonto sellaisena kuin se otetaan tutkimuksen kohteeksi ei näyttäydy suoraan havainnoissa. Sitä edustavat ja esittävät mitat ja mittaustulokset, jotka kertovat millainen luonto todella on.

Perhoniemi ottaa esiin uusien tieteellisten instrumenttien, kuten kaukoputken, mikroskoopin, ilmapuntarin ja lämpömittarin, merkityksen, mutta muun kuin tieteellisen mittaamisen sosiaalihistoria on luvussa kokonaan taustalla. Syntyy mielikuva, että Galilei toimi sosiaalisessa tyhjiössä.Tämä on hyvin harhaanjohtavaa: Galilei toimi keskellä mitä vilkkainta tutkimuksellis-intellektuaalista yhteisöä, jota huomioimatta hänen työnsä, kuten koko uuden ajan alun tieteellinen murros, jäävät käsittämättömiksi (esimerkiksi Dear 1995). Erityisesti tulisi korostaa tutkimuksen läheistä yhteyttä yhteiskunnallisten tuotannollisten käytäntöjen eri aloihin; "luonnon mekanisoi- 
tuminen" on aikakauden murrokseen usein sovellettu termi (Hadot 2006). Luonnontutkijat, Galilei muiden mukana, vetosivat yleisesti kokemuksiin, joita käsityöläiset olivat parin edeltäneen vuosisadan kuluessa saavuttaneet esimerkiksi metallurgian, aseiden valmistuksen ja merenkulun alalla. Vastaavanlaisia yhteyksiä luonnontuntemuksella oli taiteeseen ja arkkitehtuuriin: esimerkkejä tarjoavat Brunelleschin perspektiivi, Dürerin luontotutkielmat, Leonardon tekniset kokeilut, ja niin edelleen. Barbara Maria Stafford (1994) kuvaa hienosti ja havainnollisesti eurooppalaista valistusta edeltäneen aikakauden tieteen kaikkiin suuntiin haaroneita intellektuaalisia yhteyksiä.

Uusimman, 1800-luvulla käynnistyneen tieteellisen murroksen Perhoniemi ottaa esiin luvussa "Metrijärjestelmä inhimillisenä luomuksena". Luvun keskeinen teema on 1700-luvun lopulla käynnistynyt pyrkimys standardoida mittajärjestelmät. Tämän kehityksen ensisijainen tavoite oli luoda pituusmitalle yksi kaikkialla pätevä perusyksikkö, metri. Tavoitteen toteuttaminen käsitti kaksi kysymystä: voiko pituusmitan perusyksikölle löytää jonkin luonnollisen perustan, ja jos ei voi, miten sille voidaan konstruoida luotettava prototyyppi.

Pyrkimykset luoda metrille luonnon mittauksilla todennettava "luonnollinen" perusta epäonnistuivat moninaisten vaiheiden jälkeen, ja lopulta metriä vakiintui edustamaan Pariisiin talletettu platinasta (myöhemmin platinaseoksesta) valmistettu prototyyppi,"mittanormaali". Ensimmäinen metrin malli valmistettiin pian vallankumouksen jälkeen vuonna 1799 . Hiukan erilaiset metrin aineelliset mallit palvelivat samaa tehtävää 1900-luvun jälkipuoliskolle asti. Perhoniemi kuvaa tämän kehityksen vaiheet yksityiskohtaisesti ja perustelee kuvauksen jälkeen mitan kolmannen muunnelman (s.161; kursivointi alkutekstissä):

Kutsun metrin määrittämisen motivaatioiden ja sitä luonnehtivien keskeisten piirteiden perusteella muodostettua mitan muunnelmaa toiminnalliseksi. [...] (H)uomio suuntautuu metriin nimenomaan osana toimivaa metrijärjestelmää, jota ilman metriä ei voisi olla siinä merkityksessä kuin sen ymmärrämme.

Termi "metrijärjestelmä" viittaa pyrkimykseen standardoida tieteellisessä ja teknisessä mittaamisessa käytetyt yksiköt yhdenmukaisiksi kautta maailman sekä yhdistää erilaisia fysikaalisia ominaisuuksia mittaavien suureiden (muuttujien) kokonaisjärjestelmä niin yksinkertaiseksi kuin suinkin mahdollista. Taustalla oli myös fysiikan kehitys 1800-luvulla; sen seurauksena aiemmin erillisiksi oletetut alat yhdistyivät saman käsitteellisen kokonaisuuden piiriin. Tähän yhteyteen Perhoniemi liittää aivan oikein myös teollisuuden ja kaupan standardoimisen tarpeet; tosin vain mainintana. Tulkintakirjallisuus 1800-luvun jälkeisestä tieteen kehityksestä onkin jättimäisen laajaa, sen hallitseminen ei olisi mitenkään mahdollista.

Osatutkimuksia seuraa Perhoniemen tutkielman päätelmäluku "Ihmisen tieto maailmasta". Hän aloittaa sen seuraavasti (s. 175):

Muunnelmat kertovat hallinnan ja manipuloinnin lisääntymisestä sekä toismaailmallisten ja ihanteellisten oletusten korvautumisesta käytännöllisillä järjestelyillä. Samalla kun luontoa on käsitteellistetty koko ajan laajemmin mitattavaksi ja sitä on mitattu entistä tarkemmin, ovat myös käsitykset ihmisestä ja yhteiskunnasta muuttuneet.

Kuten lainaus osoittaa, Perhoniemi asettaa mitat ja mittaamisen hyvin keskeiseen asemaan arviossaan yhteiskunnallisen kehityksen olennaisista piirteistä. Luvussa hän tarjoaa kuitenkin lukijalle valitettavan löysää pohdintaa. Perhoniemi ei varsinaisesti palaa siinä käsittelemään aiempia jaksoja, eikä myöskään käytä aiemmissa jaksoissa omaksumiaan käsitteellisiä työvälineitä. Jaksoon sisätyy hyviä oivalluksia, kuten se, että uudenlaisia yhteiskunnallisia ilmiöitä on todennettava kehittämällä uudenlaisia mittoja; tällainen ilmiö on esimerkiksi ilmastonmuutos. Tosin tähän 
kohtaan on jäänyt triviaali lapsus: ilmastonmuutoksen todentamista eivät palvele "ilman happi- sekä hiilipitoisuutta kuvaavat aineistot" (s. 184), vaan seurannan kohteina ovat nimetyt kasvihuonekaasut, erityisesti hiilidioksidi. Happipitoisuudella ei ole asian kanssa tekemistä - se on ilmastonmuutoksen aikamittakaavassa vakio.

Kokonaisuudessaan Perhoniemen tutkielma jättää jälkeensä ristiriitaisen vaikutelman. Osatutkimukset ovat kiinnostavia, mutta teoksen keskeiseksi ongelmaksi paljastuu osatutkimusten heikko yhteys päätelmiin. Tämän ratkaiseva syy on käsittääkseni se, että kolmeksi "mitan muunnelmaksi" pelkistyvä historiallinen tulkinta ei ole riittävän erottelukykyinen mitan ja mittaamisen perustana olevien tekijöiden suhteen. Välitys mittaamisen käytännöllisistä taidoista ja tarpeista mitan "ideaalikäsitteeseen" on liian ohut.

Palatkaamme alkuun. Onko hedelmällistä käsitellä mittaa käsitteenä? Perhoniemi olettaa näin. Hän esittää kuitenkin olettamukselle varsin keveät perustelut; lainasin osaa näistä jo edellä,lisäksi esimerkiksi (s.15):"Mittaamisen historian moninaisuudesta paljastuu toisistaan poikkeavia ja osin ristiriitaisiakin merkitysjuonteita. Juuri nämä merkitysjuonteet osoittavat mitan käsitteellistä luonnetta." - Tämä on kuitenkin heikko perustelu. Luontevampaa olisi tulkita erilaiset merkitysjuonteet osoitukseksi siitä, että mitta ei ole yhtenäinen käsite. Mitan olettaminen yhtenäiseksi käsitteeksi sitoo sen osaksi platonilaista ideaalimaailmaa.

Mikä mitta siis on? Mitta on käytännö1linen työväline, jota tarvitaan erilaisten käytännöllisten toimien toteuttamiseksi. Tällaisia käytännöllisiä toimia on monenlaisia, ja on aina ollut järjestyneiden yhteisöjen koko olemassaolon aikana. Näin ollen mittoja on myös monenlaisia. Tämän me tiedämme arkikokemuksesta, aivan samoin kuin tunnemme arkikokemuksen perusteella konkreettisten työvälineiden moninaisuuden. Emme tartu paistinlastaan ryhtyessämme pilkkomaan saunapuita, emmekä kirveeseen paistaessam- me kananmunia, ja niin edelleen. Työvälineet ovat omissa käyttöyhteyksissään välttämättömiä, mutta työväline ei ole käsite.

Mitan perustana on verbi mitata. Mitta ja mitata ovat samanlaisessa suhteessa toisiinsa kuin käsite ja käsittää. Erilaiset mitat on kehitetty kukin jotakin tarkoitusta varten: mitoilla mitataan, ja mittaamalla saadut tulokset ovat käyttökelpoisia joihinkin muihin tarkoituksiin, jokainen mitta omaansa. Tällainen on myös käsitteiden ja käsittämisen suhde: käsitteet on johdettu jotakin varten - useimmiten hyvin käytännöllisperäisestä sanastosta lähtien. Käsitteillä käsitetään, ja käsittäminen tukee joitakin muita tarkoitusperiä.

Mittojen osalta edellä esittämäni ei juuri aiheuttane erimielisyyksiä. Käsitteiden suhteen luultavasti erimielisyyksiä syntyy sitäkin enemmän. Vallitsevaa ymmärrystä etenkin tieteellisten käsitteiden merkityksestä ja tavoitteista rasittaa Platonin perintö: Kuvittelemme lähes automaattisesti, että käsitteiden avulla saavutettu käsittäminen määrittelee itse oman tarkoituksensa: saada selville "kosmoksen (olemisen) tarkoitus", tyydyttää "inhimillinen tiedon jano", tavoittaa"totuus", tai jotakin yhtä ylevää. Nietzsche ja Foucault ovat tunnettuja tällaisen näkökannan kriitikoita. Chuck Dyke (2006) käyttää ihanteesta nimitystä "monoteistinen tiede".

Perhoniemen tutkielmaa hallitseva mitan käsiteluonteen korostaminen hävittää osatutkimusten teemojen moninaiset käytännölliset yhteydet. Tämä vääristää myös historiallisten tapauskuvausten tulkintoja. Platonilaiseen "kosmos"-käsitykseen sitoutunut antiikkia koskeva tulkinta "ontologinen" on harhaanjohtava. Toisen ja kolmannen muunnelman erottaminen toisistaan on puolestaan keinotekoista, sillä luonnon mekanisoitumisen kannustama Galilein aikainen tiede oli aivan yhtä toiminnallista kuin metrijärjestelmän tuottanut tiede. Galilei irtoaa historiallisesta käsityöläisyyden, vilkastuvan kaupan ja orastavan teollisuuden tuottamasta käytännöllisten taitojen yhteydestä, johon hän kuuluu. Toisaalta yksi metrijärjestelmän kehittämistä määrittä- 
vistä taustoista oli 1800-luvun comtelainen positivismi, jota atribuutti "representatiivinen" osuvasti luonnehtii.

Perhoniemen empiiriset käsitehistorialliset tapaustutkimukset ovat erinomaisia, mutta ongelmanasettelun kokonaisuus hajoaa. Olisi ollut parempi ratkaisu kohdistaa teos selvemmin osatutkimusten ilmentämiin tieteellistä mittaamista koskeviin käsityksiin ja sivuuttaa

\section{KIRJALLISUUS}

Dear, Peter (1995). Discipline E' Experience. The Mathematical Way in the Scientific Revolution. The University of Chicago Press.

Dyke, Chuck (2006). Natural speech: a hoary story. Teoksessa: Yrjö Haila \& Chuck Dyke (toim.), How Nature Speaks. The Dynamics of the Human Ecological Condition. Duke University Press, 66-77.

Gamble, Clive (2007). Origins and Revolutions. Human Identity in Earliest Prehistory. Cambridge University Press.

Hadot, Pierre (2006). The Veil of Isis. An Essay on the History of the Idea of Nature. The Belknap Press of Harvard University Press. ihmisyyden ehtoihin ulottuvat yleistävät päätelmät. Kirja on kehystetty liian laaja-alaiseksi, mitä ilmentää sen alaotsikko: "Miten määritämme maailmaa, ihmistä ja tietoa". Eivät mitat tästä suoriudu! Alaotsikko olisi voinut olla esimerkiksi: "Miten mittaamalla on koetettu hallita maailmaa, mutta enimmäkseen epäonnistuttu".

- YRJÖ HAILA

McEwen, Indra Kagis (1993). Socrates' Ancestor. An Essay on Architectural Beginnings. MIT Press.

Morley, Iain \& Colin Renfrew, toim. (2010). The Archaeology of Measurement. Comprehending Heaven, Earth and Time in Ancient Societies. Cambridge University Press. Rykwert, Joseph (1988). The Idea of a Town. The Anthropology of Urban Form in Rome, Italy and the Ancient World. 2nd ed. The MIT Press.

Stafford, Barbara Maria (1994). Artful Science. Enlightenment Entertainment and the Eclipse of Visual Education. The Mit Press.

Vernant, Jean-Pierre (2006). Myth and Thought among the Greeks. Zone Books. 